Jurnal Penelitian Hukum De Jure

Volume 21 Number 2, June 2021

P-ISSN: 1410-5632, E-ISSN: 2579-8561

Accredited No: 10/E/KPT/2019

This work is published under license Creative Commons Attribution 4.0 International License

\title{
CONTEMPORARY FIQH STUDY: SOUTH KOREA AS A COUNTRY OF APPEARANCE-ORIENTED VIEWS (외모 지상 주의) ON TREND OF COSMETIC PLASTIC SURGERY
}

\author{
Muhamad Parhan, Mohammad Rindu Fajar Islamy, Ilham Kurnia Gustavakuan, \\ Rizka Ade Purnama, Shakylla Putri Ragiel Utami \\ Universitas Pendidikan Indonesia \\ Corresponding email: parhan.muhamad@upi.edu
}

Paper received on: 22-03-2021; Revised on: 05-05-2021; Approved to be published on: 18-05-2021

DOI: http://dx.doi.org/10.30641/dejure.2021.V21.201-212

\begin{abstract}
This research attempted to find out the view of Islamic law in modern fiqh studies on plastic surgery and Appearance-oriented views (Lookism) in South Korea. The use of juridical empirical method, or also known as sociological research, aimed to provide an overview of the implementation of plastic surgery in society based on applicable law by analyzing problems in society through secondary data. According to the data from the International Society of Aesthetic Plastic Surgery (ISAPS) in 2019, South Korea was in fifth position as a country that is estimated to carry out the most plastic surgery procedures in the world, 2,571 times (5.1\%). This shows that this country has an Appearance-oriented view (Lookism) which is part of the Lookism culture. According to Bio Med Central 2017 data, there was a high ratio of recurrent discrimination rates (OR: 3.70; 95\% CI: 2.19-6.27) and 'incident' (OR: 3.10; 95\% CI: 2.99-4.83) from 2005 to 2013 against individuals in the age group of 15-24 years.
\end{abstract}

Keywords: Appearances-Oriented Views; Contemporary Fiqh; Plastic Surgery

\section{INTRODUCTION}

The rise of South Korean culture is a major phenomenon that has emerged recently. This phenomenon is often known as the Korean Wave, where South Korean culture is popular in almost all corners of the world. The Korean Wave is also known as Hallyu ${ }^{l}$, where Korean popular culture has expanded rapidly in various parts of the world since the late 1990s, and entered the lexicon of popular culture in the global world. The culture that is well-known among teenagers is Korean Pop or K-Pop which is a genre of music popularized by idol groups which are divided into boy band and girl band ${ }^{2}$. Teenagers not only love K-Pop; there is also Korean Drama or K-Drama that has high popularity. The popularity of K-Drama is driven by its storyline that stimulates the emotions of fans and the handsome and beautiful looks of the actors and actresses.

The success of Hallyu, which has been able to penetrate the international market, has certainly

\footnotetext{
Sang Un Park, "The Beauty Will Save You: The Myth and Ritual of Dieting in Korean Society," Korea Journal 47, no. 1 (2007): 41-47.

Jung Bong Choi and Roald Maliangkay, K-Pop - The International Rise of the Korean Music Industry, Humanities, Social Science, 1st Editio., vol. 24 (London: Routledge, 2015).
}

increased the interest of the South Korean and international society towards plastic surgery. Plastic surgery was originally used as a means of repairing a disability/abnormality of a part of the body so that its function returns to normal. According to the Draft Government Regulation Concept regarding medical procedure, it is stated that plastic surgery is a medical procedure related to reconstructive plastic surgery, with the aim of obtaining or restoring the shape so that the person concerned can carry out their function properly again.

Along with the growing needs of the society, plastic surgery is not only used to reconstruct defective parts of the body, but it has become a way of life in this modern era. The increasing interest in plastic surgery in South Korea makes plastic surgery a natural and cultural thing ${ }^{3}$. This makes South Korean people compete to get a beautiful and handsome dream face instantly. In fact, they are willing to pay a lot of money to get a beautiful face.

The character of South Korean society who justifies any means to get the face of their dreams

\footnotetext{
3 Kim Hai-Sook, "The Effect of Physical Attractiveness on Interpersonal Perception and Impression Judgment in Koreans," Korean Journal of Social Psychology 12, no. 3 (1993): 199-210.
} 
is supported by the development of a strong culture and religion. This makes South Korea to be called as country of Appearance-oriented views (외모 지상주의) or physical appearance-oriented ${ }^{4}$. The term appearance-oriented views is also known as lookism. Lookism is a term used to refer to positive stereotypes, prejudice, and special treatment given to people who are physically attractive or to people whose appearance conforms to cultural preferences. According to Warshurst, lookism can also be called discriminatory treatment ${ }^{5}$. This is because this culture is considered discriminatory treatment against people who are considered physically unattractive and socially ostracized, such as in the workplace, dating and other social relationships ${ }^{6}$.

The result of this research shows that, on average, individuals who are physically attractive have more friends, better social skill, and better love life. However, physical attractiveness and appearance have no effect on the level of happiness experienced by an individual. Many people judge other people based on their physical appearance which influences their response to that person ${ }^{7}$. Research on the stereotype of "What is beautiful is good" shows that overall, those who are physically attractive benefit from their appearance ${ }^{8}$, so that individuals who are physically attractive are perceived as better and have a stronger appeal to a person's competency judgment ${ }^{9}$. One of the factors in the occurrence of Appearance-oriented views or lookism in South Korea that has led to the explosion of the plastic surgery trend is because most of the South Korean population is Atheist and a small proportion of them is Buddhist, Christian and Catholic ${ }^{10}$. This

4 Ibid.

5 D. Warhurst, C., Van den Broek, D., Hall, R., \& Nickson, "Lookism: The New Frontier of Employment Discrimination?,” Journal of Industrial Relations 51, no. 1 (2009): 131-136.

6 Laura C. Eagly, Alice; Ashmore, Richard; Makhijani, Mona G.; Longo, "What Is Beautiful Is Good, But," Psychological Bulletin 110, no. 1 (1991): 109-128.

7 Hai-Sook, "The Effect of Physical Attractiveness on Interpersonal Perception and Impression Judgment in Koreans."

8 Abdul Mujib, Kepribadian Dalam Psikologi Islam (Jakarta: PT Raja Grafindo Persada, 2006).

9 Marianne Rhodes, Gillian; Simmons, Leigh; Peters, "Attractiveness and Sexual Behavior: Does Attractiveness Enhance Mating Success?," Evolution and Human Behavior 26, no. 2 (2005): 186-201.

10 Andrew Eungi Kim, "Nonofficial Religion in South increasingly strong and developing Western culture is what makes people open-minded and tend to welcome anything, especially plastic surgery ${ }^{11}$. For them, plastic surgery is not taboo or something that is prohibited by religion.

This phenomenon is interesting to study further, especially about the views of law and Islam $^{12}$, as well as in modern fiqh study on plastic surgery and appearance-oriented views (lookism) in South Korea. By knowing this, this research paper can serve as a guide and reference for someone to be an individual who is responsible, attentive to the environment and has good emotional and spiritual maturity.

\section{RESEARCH METHODOLOGY}

This research used qualitative approach by describing and analyzing contemporary fiqh study: South Korea as a country of appearance-oriented views of the trend of cosmetic plastic surgery. The method used is juridical empirical method or known as sociological research which aimed to provide an overview of the implementation of plastic surgery in society based on the applicable law by analyzing problems that occur in society through secondary data. This study not only used secondary data, but also used primary data. The Koran, hadith, journals and interviews were used as material for literature review in analyzing the problem of South Korea as a country of appearance-oriented views, country which is oriented towards physical appearance.

This was done by describing in the form of words and language using the descriptiveanalytical method, namely by collecting data and describing the results of the research. Then, the data was compiled and set forth in written form (narrative), interpreted and analyzed.

\section{DISCUSSION AND ANALYSIS}

According to the International Society of Aesthetic Plastic Surgery (ISAPS), South Korea

\footnotetext{
Korea: Prevalence of Fortunetelling and Other Forms of Divination," Review of Religious Research 46, no. 3 (2009): 284-302.

" Park Sang Un's, "The Beauty Will Save You: The Myth and Ritual of Dieting in Korean Society," Korea Journal 47, no. 2 (2007): 41-47.

${ }_{12}$ Ali Marwan HSB, "Mengkritisi Pemberlakuan Teori Fiksi Hukum (Criticising Enactment Of Law Fiction Theory)," Jurnal Penelitian Hukum De Jure 16, no. 3 (2016): 251-264.
} 
was in fifth position in the Countries Ranked by Estimated Number Of Plastic Surgeons 2019 with $2,571(5.1 \%)$ plastic surgery procedures. South Korea is the world's largest market for cosmetic or aesthetic surgery procedures. The popularity of plastic surgery in South Korea for its high quality and low price has caused the butterfly effect to spread throughout the world as more and more people come from various countries to South Korea to change their appearance ${ }^{13}$.

The phenomenon of plastic surgery that occurs in South Korea has inspired the Korean government, namely the Seoul Metropolitan Government to launch a Tourism Promotion Policy. The policy is designed to attract more overseas medical tourists to visit South Korea. In South Korea, plastic surgery has become commonplace and normal. People there think that this can be useful for increasing self-confidence. South Korean artists and people are very accustomed to taking plastic surgery to improve themselves physically ${ }^{14}$, such as enlarging the eyelids, adjusting the jaw, removing wrinkles on the face, trimming cheekbones, sharpening the nose, and thinning the lips ${ }^{15}$. South Korea is ranked fifth in the world in plastic surgery. This can be seen as in the table below:

Table 1. Countries Ranked by Estimated

Number of Plastic Surgeons ISAPS 2019

\begin{tabular}{|c|c|c|c|}
\hline RANK & COUNTRY & $\begin{array}{l}\text { NUMBER OF } \\
\text { SURGEONS }\end{array}$ & $\begin{array}{l}\text { \% OF } \\
\text { TOTAL }\end{array}$ \\
\hline (2) & USA & 6,900 & $13.7 \%$ \\
\hline (2) & Brazil & 6.017 & $11.9 \%$ \\
\hline 3 & China & 3,000 & $6.0 \%$ \\
\hline (4) & Japan & 2,707 & $5.4 \%$ \\
\hline 5 & South Korea & 2,571 & $5.7 \%$ \\
\hline 6 & India & 2,400 & $4.8 \%$ \\
\hline (7) & Mexico & 2,124 & $4.2 \%$ \\
\hline 3 & Russia & 1,812 & $3.6 \%$ \\
\hline (2) & Turkey & 1,450 & $2.9 \%$ \\
\hline 10 & Germany & 1,397 & $2.8 \%$ \\
\hline (12) & Italy & 1,390 & $2.8 \%$ \\
\hline 12 & Egypt & 1.215 & $2.4 \%$ \\
\hline 13 & Colombia & 1,130 & $2.2 \%$ \\
\hline (14) & Argentina & 1,100 & $2.2 \%$ \\
\hline 15 & France & 1,082 & $2.1 \%$ \\
\hline
\end{tabular}

Source: https://www.isaps.org/wp-content/ uploads/2020/12/Global-Survey-2019.pdf

13 Jin Hoon, "Misconceptions about Mandible Reduction Procedures," Aesthetic Plastic Surgery 29, no. 4 (2005): 317-324.

14 Ibid.

${ }^{15}$ Joanna K. Elfving-Hwang, "Man Made Beautiful: The Social Role of Grooming and Body Work in Performing Middle-Aged Corporate Masculinity in South Korea," Men and Masculinities (2020): 1-21.
In the table entitled Countries Ranked by Estimated Number of Plastic Surgeons ISAPS 2019, the first form of cosmetic surgery known to South Korea is the imitation form of eyelid surgery (blepharoplasties/eyelid surgery) which began to be performed in Japan in 1896. The operation was originally intended to treat patients who have one eye with an eyelid line and the other without an eyelid line ${ }^{16}$. Then, the technique was developed by Dr. Yu Jae Deok who opened the first teaching and training program for cosmetic surgery at Yonsei University College of Medicine in the early $1960 \mathrm{~s}^{17}$. The same thing was expressed by John Elflein ${ }^{18}$, a statistician who deals with health, disease and medical professionals. Elflein revealed that in 2018 (published December 6, 2019) South Korea was ranked fifth in the trend of plastic surgery. This can be seen as follows:

Table 2. Countries with the highest number of plastic surgeons in 2018

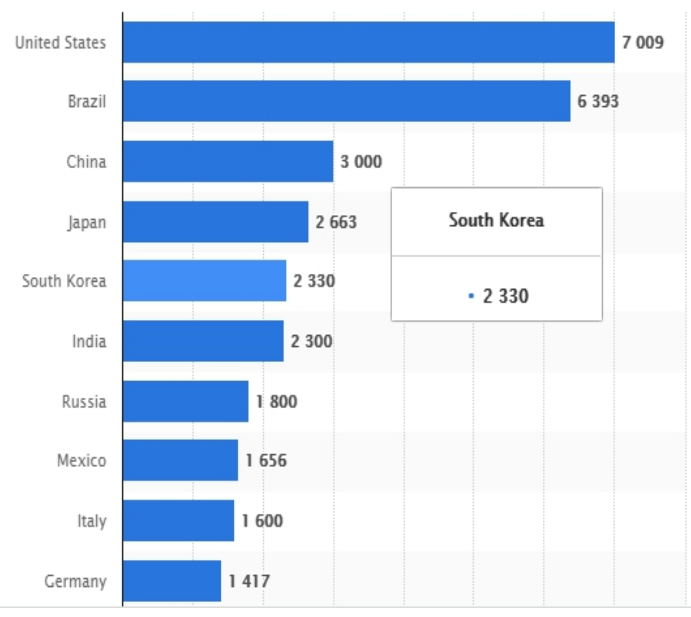

Source:https://www.statista.com/

statistics/293331/leading-countries-by-number-ofplastic-surgeons

Nowadays, cosmetic surgery has become a new culture in South Korea. When viewed from the large number of people who have taken surgery on their faces, $50 \%$ of Korean women in their 20s are said to have undergone cosmetic surgery ${ }^{19}$. In 2008 it was said that about $30 \%$ of

16 Hoon, "Misconceptions about Mandible Reduction Procedures."

17 Yonghwa Kim, The 200 Pounds Beauty (Minyeoneun Gweroweo) (Seoul: K.M. Culture Co, 2006).

18 John Elflein, "Countries with the Highest Number of Plastic Surgeons in 2018," Statista.

19 Charles Scanlon, "The Price of Beauty in South Korea," BBC News, 2015, http://news. bbc.co.uk/2 /hi/programmes/from_our_own_ correspondent/4229995.stm. 
women aged 20-50 years, estimated at around 2.5 million people, had undergone both surgical and non-surgical cosmetic procedures, and many of them had undergone it more than once ${ }^{20}$. It can be seen that the phenomenon of cosmetic surgery continues to develop from year to year, is becoming more common and is increasingly in demand by the public.

The South Korean government itself tends to be very supportive of cosmetic surgery, this can be seen from their collaboration with related institutions to form an operational consultative committee body with the aim of increasing the cosmetic surgery tourism industry by the end of 2006. Even the Korea Tourism Organization (KTO) has targeted to attract 150,000 tourists with the purpose of medical visits for cosmetic surgery in 2012 and 300,000 tourists in 2015. In addition, the Gangnam district office has collaborated with the Korea Trade Investment Promotion Agency (KOTRA) to hold medical exhibitions in Shanghai and Guangzhou on January 20-24 2012, where they provided not only information and promotional program, but also free medical consultation ${ }^{21}$. The South Korean government responded positively to the plastic surgery phenomenon because this phenomenon brings a lot of profit to the country as one of the main foreign exchange fields. This is because many foreign nationals, either from Japan, China and Taiwan, have come to Korea to undergo cosmetic surgery ${ }^{22}$. According to them, Korean cosmetic surgical techniques are known to be good, safe and reasonably priced at around $\$$ $800^{23}$. Meanwhile, in general, the public's response to this phenomenon tends to be positive. Among the younger generation, in everyday life, there are several new terms in popular Korean that are used to describe beauty, namely Momjjang (Body King/ someone with a good body), Eoljjang (Face King/

20 Martin Fackler,"In South Korea, Cosmetic Surgery Falters with Economy," The New York Times, 2009, https://

www.nytimes.com/2009/o1/o2/world/asia/o2ihtplastic.1.19049082.html?searchResultPosition=1.

${ }^{21}$ Yoon Sojung, "Number of Overseas Patients in Korea Rises by $11 \%$ in 2015," Korea.Net, 2015, https://www. korea.net/NewsFocus/policies/view?articleId=137499.

22 Shuling Huang, "Nation-Branding and Transnational Consumption: Japan-Mania and the Korean Wave in Taiwan," Media, Culture E Society 33, no. 1 (2011): 3-18.

${ }^{23}$ Hyejin Park and Han Who Park, "Research Evaluation of Asian Countries Using Altmetrics: Comparing South Korea, Japan, Taiwan, Singapore, and China," Scientometrics 117, no. 2 (2018): 771-788. someone with a handsome face), and Ssaeng'eol (natural beauty without make-up) ${ }^{24}$. Natural beauty (ssaeng'eol) is still an ideal thing ${ }^{25}$. This can be seen from the actions of celebrities who do not admit that they have undergone cosmetic surgery even though their faces have changed drastically. They want people to think they are born naturally beautiful. However, as time went by, women in general became more open to the possibility of having surgery.

According to an interview on the Asian Boss channel in 2016, in average Korean women wanted to undergo plastic surgery. Plastic surgery that was commonly wanted to be performed was on the eyelids because they wanted to enlarge the eye circle like a Westerner. The rise of plastic surgery that Korean women want to undergo is due to lookism that has become a culture, such as the existence of beauty standards on resume photos or Curriculum Vitae (CV) for applying for jobs $^{26}$. Korean companies are very competitive in selecting their employees based on first impression of appearance on job resumes as a requirement for entry to the company. For example, a photo in a $\mathrm{CV}$ is usually seen from the shape of the face, hair to the background color of the photo. This causes Korean people to undergo plastic surgery, not to beautify themselves, but to get a job.

In South Korea, the High School graduation gift for Korean teenagers is plastic surgery on the nose or blepharoplasty (double-eyelid surgery, which is the insertion of a crease in the eyelid to make the eyes look bigger). A South Korean person or someone who has lived in South Korea knows how effective someone's look in social life is. The media is one of the foundations that trigger lookism in Korean society in order to make TV shows successful. In fact, broadcasting stations only show what the public is already interested in. For example, the TV program "Let Mi In." Let Mi In is a very popular TV program in South Korea $^{27}$. This program brings in contestants who

${ }_{24}$ Park, "The Beauty Will Save You: The Myth and Ritual of Dieting in Korean Society."

25 S. S. Lee, H., Son, I., Yoon, J., \& Kim, "Lookism Hurts: Appearance Discrimination and Self-Rated Health in South Korea," International journal for equity in health 16, no. 1 (2017): 204.

${ }^{26}$ Warhurst, C., Van den Broek, D., Hall, R., \& Nickson, "Lookism: The New Frontier of Employment Discrimination?"

${ }_{27}$ Y. S. Choi, "Self-Care Will Take You to Freedom: 
are dissatisfied with their appearance and tend to be ostracized from social life ${ }^{28}$. Therefore, this program provides plastic surgery for those who have lookism problem. According to Lee ${ }^{29}$ in the Bio Med Central 2017 data, the following data were obtained:

\begin{tabular}{|c|c|c|c|c|c|}
\hline \multirow{2}{*}{$\begin{array}{l}\text { Appearance } \\
\text { discrimination }\end{array}$} & \multirow{2}{*}{$\begin{array}{l}\text { Distribution } \\
\mathrm{N}(\%)\end{array}$} & \multicolumn{2}{|c|}{ Unadjusted } & \multicolumn{2}{|c|}{ Adjusted $^{a}$} \\
\hline & & $\overline{\mathrm{OR}}$ & $95 \% \mathrm{Cl}$ & $\overline{\mathrm{OR}}$ & $95 \% \mathrm{Cl}$ \\
\hline Never & $2,513(84.5)$ & 1 & Referent & 1 & Referent \\
\hline Repeated & $74(2.5)$ & $4.79^{\circ}$ & $2.85-8.05$ & $3.70^{*}$ & $2.19-6.27$ \\
\hline Incident & $173(5.8)$ & $3.38^{*}$ & $2.17-5.26$ & $3.10^{*}$ & $1.99-4.83$ \\
\hline In error & $213(7.2)$ & 1.54 & $0.96-2.47$ & 1.21 & $0.72-2.02$ \\
\hline
\end{tabular}

Source:https://equityhealthj.biomedcentral.com/ articles/10.1186/s12939-017-0678-8/tables/3

The strength of Lookism culture in South Korea can be seen from the Bio Med Central 2017 data. The high ratio of the level of discrimination "repeated" (OR: 3.70; 95\% CI: 2.19-6.27) and "incident" (OR: 3.10; 95\% CI: 1.99-4.83) in the period of 2005 to 2013 with group of individuals of 15-24 years old. This shows the impact of the lookism phenomenon which causes discrimination in physical appearance, residential area and baseline health status ${ }^{30}$. For South Korean society, perfect physical appearance is a kind of necessity and an absolute standard. According to a survey in March 2009 from recruiting firm Saramin, about $31 \%$ of job applicants in South Korea said they are willing to undergo plastic surgery because physical appearance has become an important factor in getting a job ${ }^{31}$.

Lookism culture is a term used to refer to positive stereotype, prejudice, and special treatment given to people who are physically attractive ${ }^{32}$ or to people whose appearance matches

Weight-Loss Reality TV Shows in South Korea," in Doctoral Dissertation (Champaign: University of Illinois at Urbana, 2016).

28 B. G. Cavico, F. J., Muffler, S. C., \& Mujtaba, “Appearance Discrimination, Lookism And Lookphobia In The Workplace," Journal of Applied Business Research (JABR) 28, no. 5 (2012): 791-802.

29 Lee, H., Son, I., Yoon, J., \& Kim, "Lookism Hurts: Appearance Discrimination and Self-Rated Health in South Korea."

3o Cavico, F. J., Muffler, S. C., \& Mujtaba, "Appearance Discrimination, Lookism And Lookphobia In The Workplace."

31 Sookyung Park, "Workplace Bullying and Harassment in South Korea," in Workplace Bully Harassment, vol. 12 (Japan: Institute for Labour Policy and Training, 2013), 91-111.

32 Warhurst, C., Van den Broek, D., Hall, R., \& Nickson, "Lookism: The New Frontier of Employment cultural preference ${ }^{33}$. Lookism is discriminatory treatment to people who are considered physically unattractive, not only in the workplace, but in dating and other social settings ${ }^{34}$. A research shows that in average, physically attractive individual tends to have more friends, better social skill, and a more active sex life. However, attractiveness has no effect on the level of happiness experienced by the individual ${ }^{35}$. Many people judge other people based on their physical appearance which influences their response to those people. This shows that those who are physically attractive will benefit from their good look. Individuals who are physically attractive are perceived as more positive and that physical attractiveness has a strong influence on the judgment of one's competence $^{36}$.

The development of the media is also one of the factors of lookism. The media have a very big role in maintaining and improving the appearance in society. The development of the media has increased the interest in plastic surgery which always presents an ideal and attractive figure from a physical point of view. Attractive physical conditions are always presented to be able to enhance one's appearance and make them more acceptable in society.

Eunkook M Suh, a psychology professor at Yonsei University in Seoul, explained another factor that causes lookism. He states that in Asian societies such as South Korea, many people hold the theory of addition versus the theory of entity about one's potential ${ }^{37}$. We must also consider how competitive and cooperative the South Korean society was after the Korean War. Its GDP per capita (\$ 65) was lower than Somalia and the political regime was oppressive. Now South

Discrimination?"

33 Hai-Sook, "The Effect of Physical Attractiveness on Interpersonal Perception and Impression Judgment in Koreans."

34 Lee, H., Son, I., Yoon, J., \& Kim, "Lookism Hurts: Appearance Discrimination and Self-Rated Health in South Korea."

35 Hai-Sook, "The Effect of Physical Attractiveness on Interpersonal Perception and Impression Judgment in Koreans."

36 Rhodes,Gillian;Simmons,Leigh;Peters,"Attractiveness and Sexual Behavior: Does Attractiveness Enhance Mating Success?"

37 Eunkook M Suh, "Culture, Identity Consistency, and Subjective Well-Being," Journal of personality and social psychology 83, no. 6 (2002): 1378-1391. 
Korea has fourteenth-highest GDP ${ }^{38}$.

The discussion of plastic surgery law has not been found in classical fiqh books ${ }^{39}$. Discussions about plastic surgery are only found in modern-day fiqh books ${ }^{40}$, which are in line with the development of science and technology ${ }^{41}$. Regarding plastic surgery that has just been encountered in the modern-day figh books, if we look further, there are two objectives for the implementation of plastic surgery in the modernday fiqh book, namely: 1. Plastic surgery that aims to repair damaged bones or cells so they can function as usual. This operation is performed on people who have physical disabilities, both birth disabilities and disabilities caused by certain things such as cleft lip, burns, or disabilities due to accidents. 2. Plastic surgery which aims to beautify the shape of the body, for example, the flat nose is operated on to make it pointed ${ }^{42}$.

If you look at the character of South Korean people who are very open and religion is not the main principle, this is certainly very different from the character of Indonesian people who are based on morality and religion ${ }^{43}$ as well as human values ${ }^{44}$. Indonesia, as country with the most Muslims in the world, makes the culture and life of its people ${ }^{45}$ inseparable from Islamic religious law ${ }^{46}$. In fact, the implementation of plastic surgery

$3^{8}$ Khairy A. Tourk, "Oil Price Shocks And The Asian Newly Industrialized Countries' Response: A Case Study Of South Korea And Taiwan," The Journal of Energy and Development 16, no. 2 (1991): 255-266.

39 Mustofa and Abdul Wahid, Hukum Islam Kontemporer (Jakarta: Sinar Grafika, 2009).

40 Abdul Mujib, Kaidah-Kaidah Ilmu Fiqh Cet. 2 (Jakarta: Kalam Mulia, 2001).

${ }^{41}$ Maghfiroh, Nurl, and Heniyatun, Kajian Yuridis Operasi Plastik Sebagai Ijtihad Dalam Hukum Islam (Magelang: Fakultas Hukum Universitas Muhammadiyah, 2015).

${ }_{42}$ Mustofa and Wahid, Hukum Islam Kontemporer.

43 Abdul Jalil, "Karakter Pendidikan Untuk Membentuk Pendidikan Karakter," Nadwa 6, no. 2 (2012): 175.

44 Muhamad Parhan et al., "Internalization Values of Islamic Education at University," International Journal of Psychosocial Rehabilitation 24, no. 8 (2020): 1477814791.

45 Otom Mustomi, "Perubahan Tatanan Budaya Hukum Pada Masyarakat Adat Suku Baduy Provinsi Banten," Jurnal Penelitian Hukum De Jure 17, no. 3 (2017): 309328.

${ }_{46}$ Muhamad Parhan and Bambang Sutedja, "Penerapan Pendekatan Pembelajaran Kontekstual Dalam Pendidikan Agama Islam Di Universitas Pendidikan Indonesia," TARBAWY: Indonesian Journal of Islamic according to Islamic law and contemporary fiqh study should only be done in an emergency situation $^{47}$. However, in practice, plastic surgery is mostly performed by someone with the aim of showing off so that they look more attractive, like the appearance-oriented views phenomenon in South Korea where cosmetic/aesthetic plastic surgery due to physical appearance is common.

The fiqh scholars at least divide the legal status of plastic surgery into three types: addharūrah (primary), al-häjiyyah (secondary), and al-tahsiniyyah (tertiary). Ilham Abdullah, a contemporary scholar, states that operations that fall into the ad-dharürah category are divided into two types; first, surgical activities caused by birth defects such as blockage of the nostrils, closing the throat cleft, obstruction of the lower urethral orifice in men, kidney disorders, pelvic urethral and tumors ${ }^{48}$; second, surgical activities caused by defects that are caused by disease in humans during their life, such as changes in the shape of the ear due to cartilage erosion, cancer ${ }^{49}$ and cases of burns $\mathrm{s}^{50}$. The surgeries above are certainly done more by doctors than plastic surgery which is performed only to enhance one's appearance. This operation is of course intended to remove defects in creation, distortion, damage, or deficiencies so that the operation protects the life from destruction ${ }^{51}$.

Meanwhile, operation of the al-hajiyyah category is an operation that is carried out because there is a need to remove a defect that is triggered by something that is physically and ma'nawi destructive, but does not reach the limit of emergency (very urgent need) ${ }^{52}$. This can be in the case of removing skin deformation due to cutting machines ${ }^{53}$, cleft lip surgery, defects in

\footnotetext{
Education 6, no. 2 (November 30, 2019): 114-126.

47 Mujib, Kaidah-Kaidah Ilmu Fiqh Cet. 2.

${ }_{48}$ Muhammad An-Natsyah, Al-Masāilu At-Thibbiyyah Al-Mustajiddah Fi Dhaui Syarīah Al-Islāmiyyah (Inggris: Hikmah, 2001).

49 Izdihār Mahmūd Shābir Al-Madanī, Ahkām Tajmīl An-Nisā Fi As-Syarīah Al-Islāmiyyah (Riyadh: Dal AlFadilah, 2002).

50 Abdul Aziz bin Shalih Al-Khulaifi, Al-Ikhtiläf Al-Fiqhì F̄̄ Al-Madzhab Al-Māliki (Arab Saudi: Musthalahātuhu wa Asbābuhu., 1993).

${ }^{51}$ Muhamad Khalid Manshur, Al-Ahkām At-Thibbiyyah Al-Muta'alliqah Bi An-Nisā, Fi Al-Fiqh Al-Islami (Urdun: Dar An-Nafais, 1999).

53 Abdul Aziz bin Abdul Muhsin, Jāmi Al-Fatāwa At-
}

52 Ibid. 
the jaw caused by disease, or various accidents, restoring amputated fingers, major breast surgery due to disease, pain in the neck, shoulders, burns treatment and cases of deformation after war. Doctors mostly see that both categories of surgery are indispensable ${ }^{54}$ and are something tangible. It is not the same as plastic surgery in general in its impact contribution and consequences ${ }^{55}$.

Contemporary Muslim scholars in Islamic jurisprudence have come to an agreement on this problem, namely to legalize and permit this type of operation for several reasons; first, the defects handled by such an operation clearly include physical and moral damage, so a surgical treatment is required. This is considered a necessity by referring to the rules of sharia, namely al-hājah tanzilu manzilata ad-darūrah ammah kānat au khāssah ${ }^{56}$. Second, the application of such operations is legalized, so other operations also have the same legal consequences, which are permissible. Meanwhile, treatment surgery contains a need that concerns the dangers of pain, namely sensory pain, where this type of surgery falls into the category of sensory and ma'nawi damage $^{57}$.

It can be understood that plastic surgery that is recommended by medics with the aim of repairing damaged bones or cells so that they can function as usual, or plastic surgery which is performed with reference to surgical practices which are performed to repair or restore certain limbs to their original shape, of course, is permissible, and is not contested by scholars and fiqh experts ${ }^{58}$. However, plastic surgery that aims to beautify the body shape is mostly contested, and even tends to be prohibited ${ }^{59}$. This can be understood if

\footnotetext{
Thibbiyah Wa Al-Ahkām Al-Muta'alliqah Bihā (Riyadh: Dar Al-Qasim, 2004).

54 Muhamad Rif 'at, Al-Amaliyyāt Al-Jarāhiyyah Wa Jarāhah At-Tajmīl (Beirut: Dar Al-Ma'rifah, 1979).

55 Muhammad bin Mukhtar As-Syinqīthi, Ahkām AlJarāhah At-Thibbiyyah Wa Al-Atsār Al-Mutarattabah Alaihā (Madinah: Al-Jami'ah Al-Islamiyyah, 1997).

${ }_{56}$ Zainul Abidin bin Ibrahim bin Nujaim, Al-Asybāh Wa An-Nadzāir Alā Madzhab Ab̄i Hanifah An-Nu'mān (Beirut: Maktabah Al-Ashriyyah, 1998).

57 As-Syinqīthi, Ahkām Al-Jarāhah At-Thibbiyyah Wa AlAtsār Al-Mutarattabah Alaihā.

${ }_{58}$ Maghfiroh, Nurl, and Heniyatun, Kajian Yuridis Operasi Plastik Sebagai Ijtihad Dalam Hukum Islam.

59 Djohansjah Marzoeki, Analisis Dan Evaluasi Hukum Tentang Pengaturan Bedah Plastik (Jakarta: Badan Pembinaan Hukum Nasional, Kementerian Hukum
}

someone already has perfect body organs, then he is not allowed to undergo plastic surgery, because it is categorized as changing Allah's creation. The operation is prohibited because it contradicts the word of Allah SWT in Surah Al-Baqarah (2) verse 195, which means: “... and do not let your own hands throw you into destruction ..." The word of Allah SWT means that people who have normal body organs are prohibited from changing their shape because it is categorized as changing the creation of Allah SWT. The scholars of fiqh gave reasons why it is not permissible to undergo plastic surgery because it is based on the word of Allah in Surah An-Nisa(4) verse 119, which means: "I will certainly mislead them and delude them with empty hopes. Also, I will order them and they will slit the ears of cattle and alter Allah's creation." And whoever takes Satan as a guardian instead of Allah has certainly suffered a tremendous loss." There is also a hadith which says, "It was narrated that "Abd-Allah said: "Allah has cursed the women who do tattoos and those who ask for tattoos to be done, those who ask for their eyebrows to be plucked, and the women ask for their teeth to be filed for the purpose of beautification, changing the creation of Allah." [Hadith al-Bukhari].

The scholars differed in their interpretation of the above arguments to be used as an argumentative basis regarding the legal status of whether or not plastic surgery is permissible today. Regarding surah An-Nisa, Imam Ibn Al-Arabi in his book, Ahkām Al-Qurān, quoted the opinion of the scholars where what is meant by the phrase "tagyir kholq" or changing creation actually refers to the Jahiliyyah Arabic tradition of cutting off the ears of livestock where people hurt livestock and have the view to justify what is forbidden and vice versa $^{60}$. Aj-Juzaz argues that the above verse is related to the attitude of Jahiliyyah Arabic people in forbidding things that are permitted by Allah, that is eating livestock and they regarded the sun, moon and stones as god so this is categorized as changing what Allah has created ${ }^{61}$. As for the hadith argument as described above, the majority of scholars such as Muhamad Amin Ibn Abidin,

dan HAM Republik Indonesia, 1995).

6o Zayd Bakr bin Abdullah, Al-Madkhal Al-Mufassal Ilā Fiqh Al-Imām Ahmad Bin Hanbal Wa Takhrījāti AlAshābi. Vol. I. (Riyadh: Dar al 'Aminah, 1997).

61 Al-Qurtubi, Al-Jami' Li Ahkam Al-Quran (Beirut: Dar Ihya At Turats Al 'Arabi, 1964). 
Ibn Hajar Al-Atsqolani, Ibn Muflih and others prohibit the actions of al-washmu, an-namshu, at - tafli $^{62}$. The scholars see a strong reason for the prohibition of actions above, namely that there is a cause for changing Allah's creation.

Regarding the legal status of plastic surgery for the purpose of decorating and beautifying oneself, some scholars think that there should be an in-depth study first. One of the arguments is the hadith issued by at-Tirmidhi and Ahmad: Rasulullah SAW said that "Allah is happy to see the traces of the blessings given to His servants ${ }^{63}$ ". This hadith is used as a reference by the scholars in allowing beautification pursuant to sharia rules. This opinion is supported by the opinion of Imam Ibn Qayyim about the special reasons for prohibiting the use of tattoos and others.

Syeikh Syinqithi is a mutasyaddidin (firm) scholar where he presents a conclusion from the above verses of the Koran and hadith which shows that there is a reason for the prohibition of changing creation to decorate oneself without good reason. Dalalah which is contained in the text above tends to fall into the context of plastic surgery. The two arguments above are strong warnings and are not allowed to do so ${ }^{64}$. In contrast to Shaykh Syinqithi, Abdul Karim Zaidan prefers to be careful in forbidding this and he tends to categorize such issue as makruh ${ }^{65}$.

In the end, the majority of the scholars, especially the contemporary scholars, concluded that plastic surgery is permissible with some dhowabith (rules of limitation) to be met. Plastic surgery that is prohibited is when it focuses more on changing the body shape (tagyir khalq) without sharia reasons, such as tattoos and others so that it tends to be classified as an act that is forbidden ${ }^{66}$. Plastic surgery is only allowed for doctors who have competent qualifications in their fields.

\footnotetext{
${ }_{62}$ Muhamad Amin Ibnu Abidin, Hāsyiyah Radd AlMukhtār 'Alā Ad-Dur Al-Mukhtār Syarh Tanwīr AlAbshār (Beirut: Dar Al-Fikr, 1996).

63 At-Tirmidzi, Sunan At-Tirmidzi Al-Jāmī As-Shahih (Beirut: Dar Ihya At-Turats, n.d.).

${ }^{64}$ As-Syinqīthi, Ahkam Al-Jarahah At-Thibbiyyah, hal.193

${ }_{5}$ Abdul Karim Zaidan, Al-Mufasshal Fā Ahkām AlMar'ah Wa Bait Al-Muslim (Beirut: Dar Ar-Risalah, 2000).

${ }^{66}$ Nashir Umar, Al-Bayān Al-Khatāmi Li Mu'tamar AlAmāliyyat At-Tajmīliyyah Baina Syari Wa At-Thibbi Al-Mun'aqad Fi Ar-Riyadh (Riyadh, n.d.).
}

This opinion is supported by the famous classical scholar Ibn Qudamah in his book ${ }^{67}$. Doctors who perform plastic surgery must pay attention to every detail of their activities so that they can minimize mistakes that can be fatal to patients ${ }^{68}$. Surgical practices must not break the sharia prohibitions such as opening aurah and having a khalwat, unless it is an emergency situation and is indeed required ${ }^{69}$. Doctors must have devotion to Allah so that the surgical practice is really needed and is not tempted by mere material interests ${ }^{70}$.

People undergo plastic surgery without paying attention to the consequences because of a lack of understanding of Islamic Law knowledge ${ }^{71}$. They undergo plastic surgery because they are influenced by psychological factors, for example, people who previously felt inferior with an organ that was less than perfect (ugly) in physical form, so that the person felt inferior ${ }^{72}$. However, there are also people whose organs are perfectly shaped. Because they feel that they are not attractive enough, they will try to beautify themselves by undergoing plastic surgery ${ }^{73}$. When the reason for undergoing plastic surgery is to beautify oneself and the inferior feeling, the person will be far from gratitude to Allah, and of course this is prohibited according to the agreement of the scholars of fiqh, because this is categorized as changing body parts permanently and is not based on true medical reasons according to sharia and focuses more on changing the body shape (tagyir khalq) without sharia reasons ${ }^{74}$.

${ }_{67}$ Ibnu Qudamah, Al-Mughni Ala Mukhtashar Al-Khiraqi (Beirut: Alam Al-Kutub, n.d.).

${ }_{68}$ Abdullah Salim Al-Ghamidi, Mas'ūliyyah At-Thabīb Al-Muhanniyah (Jedah: Dar Andalus, 1977).

${ }^{69}$ Isham Muhammad Sulaeman Musa, Ad-Dhowabith As-Syar'iyyah Li Amaliyyat At-Tajmil Wa Al-Islah Wa Amaliyyat Naql Al-Wajh (Mu'tamar Malaysia, 2005).

7o Manshur, Al-Ahkām At-Thibbiyyah Al-Muta'alliqah Bi An-Nisā, Fi Al-Fiqh Al-Islami.

${ }^{71}$ Maghfiroh, Nurl, and Heniyatun, Kajian Yuridis Operasi Plastik Sebagai Ijtihad Dalam Hukum Islam.

72 E. Berscheid and E. Walster, "Physical Attractiveness.," In Advances in experimental social psychology 7 (1974): 157-215.

73 Eagly, Alice; Ashmore, Richard; Makhijani, Mona G.; Longo, "What Is Beautiful Is Good, But."

74 Umar Sulaiman Al-Asyqar, Al-Madkhal Ilā Dirāsah AlMadāris Wa Al-Madzāhib Al-Fiqhiyyah (Urdun: Dar an-Nafais, 1998). 


\section{CONCLUSION}

Based on the above discussion, it can be concluded that one of the factors in the occurrence of appearance-oriented views or lookism in South Korea that has led to the explosion of the plastic surgery trend is that most of the population of South Korea are Atheists and a few others are Buddhist, Christian and Catholic. In addition, Western culture which is getting stronger makes South Korean people open-minded and tend to welcome anything, especially plastic surgery. For them, plastic surgery is not taboo or forbidden by religion. Islamic Fiqh provides several criteria for plastic surgery. Plastic surgery is allowed when it is recommended by medics with the aim of repairing or restoring the function of certain body parts due to an accident or medics oblige such surgery. Furthermore, it is prohibited when plastic surgery has the aim of beautifying the body shape and beautifying oneself overly which is done by permanently changing the shape of the body.

\section{SUGGESTION}

Appearance-oriented views, or also known as lookism, is a culture that is more oriented towards physical appearance, which causes discrimination in appearance, residential area and baseline health status, so that South Korean people compete to beautify their physique through shortcut, namely by plastic surgery, even if there is no medical reason that requires it. This is certainly far from Islamic values and far from gratitude. Considering the character of South Korean people who are very open and that religion is not the main principle, it is very different from the character of Indonesian people who are based on religious morals and human values. Plastic surgery may be performed when there is a medical necessity and it is not against religious law.

\section{ACKNOWLEDGMENT}

The researcher would like to thank the academic community of the Korean Language Education Study Program, the Faculty of Language and Literature Education, Indonesia University of Education, and the researcher would also like to thank the entire team of the De Jure Legal Research Journal who has provided the opportunity, guided and directed the researcher in preparing this scientific paper, so that this paper gets better.

\section{BIBLIOGRAPHY}

Abdullah, Zayd Bakr bin. Al-Madkhal Al-Mufassal Ilā Fiqh Al-Imām Ahmad Bin Hanbal Wa Takhrījāti Al-Ashābi. Vol. I. Riyadh: Dar al 'Aminah, 1997.

Abidin, Muhamad Amin Ibnu. Hāsyiyah Radd Al-Mukhtār 'Alā Ad-Dur Al-Mukhtār Syarh Tanwīr Al-Abshār. Beirut: Dar Al-Fikr, 1996.

Al-Asyqar, Umar Sulaiman. Al-Madkhal Ilā Dirāsah Al-Madāris Wa Al-Madzāhib AlFiqhiyyah. Urdun: Dar an-Nafais, 1998.

Al-Ghamidi, Abdullah Salim. Mas'ūliyyah AtThabīb Al-Muhanniyah. Jedah: Dar Andalus, 1997.

Al-Khulaifi, Abdul Aziz bin Shalih. Al-Ikhtilāf AlFiqhī F̄̄ Al-Madzhab Al-Māliki. Arab Saudi: Musthalahātuhu wa Asbābuhu., 1993.

Al-Madanī, Izdihār Mahmūd Shābir. Ahkām Tajmīl An-Nisā Fi As-Syarī'ah Al-Islāmiyyah. Riyadh: Dal Al-Fadilah, 2002.

Al-Qurtubi. Al-Jami' Li Ahkam Al-Quran. Beirut: Dar Ihya At Turats Al 'Arabi, 1964.

An-Natsyah, Muhammad. Al-Masāilu AtThibbiyyah Al-Mustajiddah Fi Dhaui Syarīah Al-Islāmiyyah. Inggris: Hikmah, 2001.

As-Syinqīthi, Muhammad bin Mukhtar. Ahkām Al-Jarāhah At-Thibbiyyah Wa Al-Atsār AlMutarattabah Alaihā. Madinah: Al-Jami'ah Al-Islamiyyah, 1997.

At-Tirmidzi. Sunan At-Tirmidzi Al-Jāmī AsShahih. Beirut: Dar Ihya At-Turats, n.d.

Berscheid, E., and E. Walster. "Physical Attractiveness." In Advances in experimental social psychology 7 (1974): 157-215.

Cavico, F. J., Muffler, S. C., \& Mujtaba, B. G. "Appearance Discrimination, Lookism And Lookphobia In The Workplace." Journal of Applied Business Research (JABR) 28, no. 5 (2012): 791-802.

Choi, Jung Bong, and Roald Maliangkay. K-PopThe International Rise of the Korean Music Industry. Humanities, Social Science. 1st Editio. Vol. 24. London: Routledge, 2015. 
Choi, Y. S. "Self-Care Will Take You to Freedom: Weight-Loss Reality TV Shows in South Korea." In Doctoral Dissertation. Champaign: University of Illinois at Urbana, 2016.

Eagly, Alice; Ashmore, Richard; Makhijani, Mona G.; Longo, Laura C. "What Is Beautiful Is Good, But." Psychological Bulletin 110, no. 1 (1991): 109-128.

Elflein, John. "Countries with the Highest Number of Plastic Surgeons in 2018." Statista.

Elfving-Hwang, Joanna K. "Man Made Beautiful: The Social Role of Grooming and Body Work in Performing Middle-Aged Corporate Masculinity in South Korea." Men and Masculinities (2020): 1-21.

Fackler, Martin. "In South Korea, Cosmetic Surgery Falters with Economy." The New York Times, 2009. https://www.nytimes.com/2009/01/02/ world/asia/02iht-plastic.1.19049082. html? searchResultPosition=1.

Hai-Sook, Kim. "The Effet of Physical Attractiveness on Interpersonal Perception and Impression Judgment in Koreans." Korean Journal of Social Psychology 12, no. 3 (1993): 199-210.

Hoon, Jin. "Misconceptions about Mandible Reduction Procedures." Aesthetic Plastic Surgery 29, no. 4 (2005): 317-324.

HSB, Ali Marwan. "Mengkritisi Pemberlakuan Teori Fiksi Hukum (Criticising Enactment Of Law Fiction Theory)." Jurnal Penelitian Hukum De Jure 16, no. 3 (2016): 251-264.

Huang, Shuling. "Nation-Branding and Transnational Consumption: Japan-Mania and the Korean Wave in Taiwan." Media, Culture \& Society 33, no. 1 (2011): 3-18.

Jalil, Abdul. "Karakter Pendidikan Untuk Membentuk Pendidikan Karakter." Nadwa 6, no. 2 (2016): 175.

Kim, Andrew Eungi. "Nonofficial Religion in South Korea: Prevalence of Fortunetelling and Other Forms of Divination." Review of Religious Research 46, no. 3 (2009): 284302.
Kim, Yonghwa. The 200 Pounds Beauty (Minyeoneun Gweroweo). Seoul: K.M. Culture Co, 2006.

Lee, H., Son, I., Yoon, J., \& Kim, S. S. "Lookism Hurts: Appearance Discrimination and SelfRated Health in South Korea." International journal for equity in health 16, no. 1 (2017): 204.

Maghfiroh, Nurl, and Heniyatun. Kajian Yuridis Operasi Plastik Sebagai Ijtihad Dalam Hukum Islam. Magelang: Fakultas Hukum Universitas Muhammadiyah, 2015.

Manshur, Muhamad Khalid. Al-Ahkām AtThibbiyyah Al-Muta'alliqah Bi An-Nisā, Fi Al-Figh Al-Islami. Urdun: Dar An-Nafais, 1999.

Marzoeki, Djohansjah. Analisis Dan Evaluasi Hukum Tentang Pengaturan Bedah Plastik. Jakarta: Badan Pembinaan Hukum Nasional, Kementerian Hukum dan HAM Republik Indonesia, 1995.

Muhsin, Abdul Aziz bin Abdul. Jāmi Al-Fatāwa At-Thibbiyah Wa Al-Ahkām Al-Muta'alliqah Bihā. Riyadh: Dar Al-Qasim, 2004.

Mujib, Abdul. Kaidah-Kaidah Ilmu Fiqh Cet. 2. Jakarta: Kalam Mulia, 2001.

Kepribadian Dalam Psikologi Islam. Jakarta: PT Raja Grafindo Persada, 2006.

Musa, Isham Muhammad Sulaeman. AdDhowabith As-Syar'iyyah Li Amaliyyat AtTajmil Wa Al-Islah Wa Amaliyyat Naql AlWajh. Mu'tamar Malaysia, 2005.

Mustofa, and Abdul Wahid. Hukum Islam Kontemporer. Jakarta: Sinar Grafika, 2009.

Mustomi, Otom. "Perubahan Tatanan Budaya Hukum Pada Masyarakat Adat Suku Baduy Provinsi Banten.” Jurnal Penelitian Hukum De Jure 17, no. 3 (2017): 309-328.

Nujaim, Zainul Abidin bin Ibrahim bin. AlAsybāh Wa An-Nadzāir Alā Madzhab Abì Hanifah An-Nu'mān. Beirut: Maktabah AlAshriyyah, 1998.

Parhan, Muhamad, Aiman Faiz, Abdul Karim, Risris Hari Nugraha, Ganjar Eka Subakti, Mohammad Rindu Fajar Islamy, Nurti Budiyanti, Ahmad Fuadin, and Yusuf Ali 
Tantowi. "Internalization Values of Islamic Education at University." International Journal of Psychosocial Rehabilitation 24, no. 8 (2020): 14778-14791.

Parhan, Muhamad, and Bambang Sutedja. "Penerapan Pendekatan Pembelajaran Kontekstual dalam Pendidikan Agama Islam di Universitas Pendidikan Indonesia." TARBAWY : Indonesian Journal of Islamic Education 6, no. 2 (November 30, 2019): 114-126.

Park, Hyejin, and Han Who Park. "Research Evaluation of Asian Countries Using Altmetrics: Comparing South Korea, Japan, Taiwan, Singapore, and China." Scientometrics 117, no. 2 (2018): 771-788.

Park, Sang Un. "The Beauty Will Save You: The Myth and Ritual of Dieting in Korean Society." Korea Journal 47, no. 1 (2007): 41-47.

Park, Sookyung. "Workplace Bullying and Harassment in South Korea." In Workplace Bully Harassment, 12:91-111. Japan: Institute for Labour Policy and Training, 2013.

Qudamah, Ibnu. Al-Mughni Ala Mukhtashar AlKhiraqi. Beirut: Alam Al-Kutub, n.d.

Rhodes, Gillian; Simmons, Leigh; Peters, Marianne. "Attractiveness and Sexual Behavior: Does Attractiveness Enhance Mating Success?" Evolution and Human Behavior 26, no. 2 (2005): 186-201.

Rif'at, Muhamad. Al-Amaliyyāt Al-Jarāhiyyah Wa Jarāhah At-Tajmīl. Beirut: Dar Al-Ma'rifah, 1979.

Scanlon, Charles. "The Price of Beauty in South Korea." BBC News, 2015. http://news.bbc. co.uk/2/hi/programmes/from_our_own_ correspondent/4229995.stm.

Sojung, Yoon. "Number of Overseas Patients in Korea Rises by $11 \%$ in 2015." Korea.Net, 2015. https://www.korea.net/NewsFocus/ policies/view?articleId=137499.

Suh, Eunkook M. "Culture, Identity Consistency, and Subjective Well-Being." Journal of personality and social psychology 83, no. 6 (2002): 1378-1391.
Tourk, Khairy A. "Oil Price Shocks And The Asian Newly Industrialized Countries' Response: A Case Study Of South Korea And Taiwan." The Journal of Energy and Development 16, no. 2 (1991): 255-266.

Umar, Nashir. Al-Bayān Al-Khatāmi Li Mu'tamar Al-Amāliyyat At-Tajmīliyyah Baina Syar'i Wa At-Thibbi Al-Mun'aqad Fi Ar-Riyadh. Riyadh, n.d.

Un's, Park Sang. "The Beauty Will Save You: The Myth and Ritual of Dieting in Korean Society." Korea Journal 47, no. 2 (2007): 41-47.

Warhurst, C., Van den Broek, D., Hall, R., \& Nickson, D. "Lookism: The New Frontier of Employment Discrimination?" Journal of Industrial Relations 51, no. 1 (2009): 131136.

Zaidan, Abdul Karim. Al-Mufasshal Fā Ahkām Al-Mar'ah Wa Bait Al-Muslim. Beirut: Dar Ar-Risalah, 2000.

\section{Internet}

Emma Reynolds, "The Dark Side of K-Pop: What Lurks Beneath the Surface o this Perfect Plastic World", 8 November 2014 (http:// www.news.com.au/entertainment/music/thedark-side-of-kpop-what-lurksbeneath-thesurface-of-this-perfect-plastic-world/storye6frfn09-1227116617713)

Seunjin, Nam. 2002. Lookism Ideology of Moderner. www.isaps.org

http://asiaenglish.visitkorea.or.kr/ena/bs/tour investment_support/invest_guidance/ content/cms_view_655066.jsp

https://equityhealthj.biomedcentral.com/ articles/10.1186/s12939-017-0678-8/tables/3

https://www.statista.com/statistics/293331/ leading-countries-by-number-of-plasticsurgeons

https://www.isaps.org/wp-content/ uploads/2020/12/Global-Survey-2019.pdf 
HALAMAN KOSONG

212 Jurnal Penelitian Hukum De Jure Vol. 21 No. 2, Juni 2021: 201-212 